Anne Sütü ve Emzirme ile İlgili Anneler Tarafından Bilinen Doğrular ve Yanlışlar

\title{
True and Falses Known by The Mothers About Mother Milk and Breastfeeding
}

Özlem Öztürk ${ }^{1}$, Pelin $\quad$ Sarıkaya ${ }^{2}$, Şeymanur $\quad$ Özdemir $^{2}$, Zeynep Çikendin², Nurşen $\quad$ Zünbül ${ }^{3}$

${ }^{1}$ Karabük Üniversitesi Sağlık Bilimleri Fakültesi, Çocuk Sağlığg ve Hastalıkları Hemşireliği A.D

${ }^{2}$ Karabük Üniversitesi Sağl1k Bilimleri Enstitüsü, Hemşirelik A.D

${ }^{3}$ Özel Biga Can Hastanesi, Hemşirelik Hizmetleri

\section{$\ddot{O} Z$ :}

GIRIŞ̧ ve AMAÇ: Bu çalışma, anne sütü ve emzirme ile ilgili anneler tarafından bilenen doğrular ve yanlışların neler olduğunun incelenmesi amacıyla tanımlayıcı olarak yapılmıştır.

YÖNTEM ve GEREÇLER: Araştırma, 1 Ocak - 1 Mart 2015 tarihleri arasında Eğitim ve Araştırma Hastanesinde 0-2 yaş grubu bebeği yatan 250 annenin katılımı ile gerçekleştirilmiştir. Veri toplama aracı olarak, 32 sorunun yer aldığ 1 anket formu ve annelerin anne sütü ve emzirmeye yönelik bilgilerini değerlendiren 34 ifadenin yer aldığı tanımlayıcı form kullanılmıştır. Verilerin değerlendirilmesinde istatistiksel analizler kullanılmıştır.

BULGULAR: Çalışmaya katılan annelerin yaş ortalaması 28.7 olup, \%27.6'sının ilkokul mezunu ve \%87.2'sinin ev hanımı olduğu saptanmıştır. Annelerin \%85.6'sının anne sütü ve emzirme ile ilgili bilgi aldığı, bilgi edinme kaynaklarında \%56 ile sağlık personelinin ilk sırada yer aldığı belirlenmiştir. Annelerin \%41.6's1 "Buzdolabından çıkarılan anne sütü ocakta 1sıtıldıktan sonra bebeğe verilmelidir" ifadesine, \%71.2'si “Göğüsler her emzirmeden önce karbonatl veya sabunlu suyla temizlenir” ifadesine evet demiştir. Annelerin bilgi alma durumları ile anne sütü ve emzirmeye yönelik ifadelere verdikleri yanıtlar karşılaştırıldığında, annelerin bilgi alma durumları ile sekiz ifade arasında istatistiksel olarak anlamlı fark bulunmuştur $(\mathrm{p}<0.05)$.

TARTIŞMA ve SONUÇ: Çalışmaya katılan annelerin büyük çoğunluğu anne sütü ve emzirme ile ilgili bilgi almış olmalarına rağmen, anne sütü ve emzirmeye yönelik bilgilerinin yeterli olmadığ1 görülmüştür.

Anahtar Kelimeler: Anne sütü, emzirme, bebek, sağlik eğitimi. 


\section{SUMMARY:}

INTRODUCTION: This study was performed descriptively to investigate true and falses known by the mothers about mother milk and breastfeeding.

METHODS: The study was performed with 250 mothers whose infants between 0-2 years old were hospitalized in Research and Training Hospital between January 1 - March 1, 2015. A questionnaire including 32 questions and a descriptive form including 34 statements which were evaluating knoledge of the mothers about mother milk and breastfeeding were used as data collection tools. Statistical analyses were used for the assessment of data.

RESULTS: Mean age of the mothers in the study was 28.7 years; $27.6 \%$ were elementary school graduates and $87.2 \%$ were housewives. It was determined that $85.6 \%$ of the mothers were informed about mother milk and breastfeeding, and healthcare professionals were found to be in the first place by $56 \%$ for information resources. $41.6 \%$ of the mothers gave "yes" response to the statement of "Mother milk in the refrigerator should be warmed before given to the baby"; $71.2 \%$ gave "yes" response to the statement of "Breasts are cleaned with carbonated or soapy water before each breastfeeding". When the responses of the mothers for their status of getting information and for mother milk and breastfeeding were compared, a statistically significant difference was found between their status of getting information and eight statements $(\mathrm{p}<0.05)$.

DISCUSSION and CONCLUSION: Although majority of the mothers in the study were informed about breast milk and breastfeeding, it was observed that their knowledge about mother milk and breastfeeding was not enough.

Keywords: Breast milk, breastfeeding, infant, health education. 


\section{Giriş}

Anne sütü ile beslenmenin bebek, anne ve topluma nutrisyonel, immünolojik, gelişimsel, sosyal ve ekonomik birçok yararı vardır (1). Anne sütü özellikle kolostrum, enfeksiyonlara karşı pasif koruyuculuk sağlayan besinleri içerir (2). Emzirme, bebeğin sağlıklı büyüme ve gelişmesini sağlarken, bebeklerde otitis media, gastroenterit, nekrotizan enterokolit, alt solunum yolu ve üriner sistem enfeksiyonları, bakteriyel menenjit, alerjik hastalıklar, obezite, diyabet, çölyak hastalığı, çocukluk çağı lösemisi gibi akut ve kronik hastalık risklerini azaltır (3-5). Ayrıca emzirme ile ani bebek ölüm sendromu riskinin \%36 oranında azaldığı belirlenmiştir. Anne sütünün ilk altı ay tek başına, bir yıl sonrasında da ek gıdalar ile birlikte verilmesinin dünyadaki çocukluk çağı ölümlerini \%13 oranında önlediği, bir yılda bir milyondan fazla bebek ölümlerini önleyebileceği bildirilmiştir (6).

Dünya Sağlık Örgütü (DSÖ) ve Birleşmiş Milletler Çocuklara Yardım Fonu (United Nations International Children's Emergency Found "UNICEF") bebeklerin doğumdan itibaren ilk altı ay sadece anne sütü ile beslenmesini ve yedinci aydan itibaren ek gıdalar verilmesinin yanında, emzirmeye iki yaşına kadar devam edilmesini önermektedir (7). Amerikan Pediatri Akademisi (American Academy of Pediatrics “AAP”) ise, ilk altı ay sadece anne sütü, altı ay sonrasında ek gıdalar ile birlikte bir yıl veya daha uzun süre anne sütü kullanımını önermektedir(6).

Türkiye Nüfus ve Sağlık Araştırması (TNSA) 2013 verilerine göre, Türkiye'de bir süre emzirilen çocukların oranı \%96 iken, altı aydan küçük bebeklerde sadece anne sütü ile beslenme oranı $\% 30.1$ ve ortanca sadece anne sütü ile beslenme süresi 1,2 aydır (8). Ülkemizde, emzirme yaygın olmasına rağmen, bebeği emzirmeye geç başlama, ilk emzirmeden önce şekerli su gibi besinler verme, ek besinlere erken ya da çok geç başlama gibi hatalı uygulamalar, kaliteli bir emzirme programını ve emzirmenin olumlu etkilerinin görülmesini engellemektedir $(9,10)$.

Yapılan çalışmalar, emzirme eğitimi ve danışmanlık hizmetlerinin emzirmenin başlatılması ve sürdürülmesi oranlarını önemli ölçüde arttığını göstermiştir $(11,12)$. Toplumda ek besinlere erken başlama ve anne sütünden erken kesme eğilimi nedeniyle, annelerin doğum öncesi ve sonrası eğitim programları ile bilinçlendirilmesi konusunda sağlık profesyonellerine önemli görevler düşmektedir(12). Sağlık profesyonelleri arasında yer alan hemşireler ise, annelerin hatalı emzirme davranışlarının uygun olan davranışlar ile değiştirilmesinde kritik role sahiptir. (13). Bu bağlamda bu çalışma, anne sütü ve emzirme ile ilgili anneler tarafından bilenen doğrular ve yanlışların neler olduğunun incelenmesi amacıyla tanımlayıcı olarak yapılmıştır.

\section{Gereç ve Yöntemler}

Tanımlayıcı ve kesitsel tipteki bu çalışma, 1 Ocak-1 Mart 2015 tarihleri arasında Karabük Üniversitesi Eğitim ve Araştırma Hastanesi'nde gerçekleştirilmiştir. Araştırmanın yürütüldüğü tarihlerde hastaneye 0-2 yaş grubu 261 bebeğin yatışı yapılmıştır. Araştırmanın örneklemini, belirtilen tarihlerde 0-2 yaş grubu bebeği yatan ve araştırmaya katılmayı kabul eden 250 anne oluşturmuştur. Araştırmada veri toplama aracı olarak, araştırmacılar tarafından hazırlanan 32 sorunun yer aldığı anket 
formu ve annelerin anne sütü ve emzirmeye yönelik bilgilerini değerlendiren 34 ifadenin yer aldı̆̆ tanımlayıcı form kullanılmıştır.

Araştırmanının yapılabilmesi için Karabük Üniversitesi Etik Kurulundan etik kurul izni ve Karabük Üniversitesi Eğitim ve Araştırma Hastanesinden kurum izni alınmıştır. Araştırma hakkında bilgi verilerek ve gönüllülük ilkesi ön planda tutularak, sözlü onamları alınmıştır. Veriler yüz yüze görüşme tekniği ile toplanmıştır. Veri toplama aşaması sonrası, annelerin tanımlayıcı formda yer alan ifadelerde yapmış oldukları yanlış değerlendirmelerin doğruları hakkında annelere bilgi verilmiştir.

Verilerin istatistiksel değerlendirmesinde SPSS 15.0 programı kullanılmıştır. Tanımlayıcı istatistiklerde, kategorik yapıdaki veriler sayı ve yüzde olarak ifade edilmiştir. Kategorik yapıdaki değişkenler bakımından gruplar arası farklılıklar Ki-kare testi ile incelenmiştir. Sonuçlar \%95 güven aralığında değerlendirilmiş ve $\mathrm{p}<0.05$ değeri anlamlı kabul edilmiştir.

\section{Bulgular}

Çalışmaya 250 anne katılmış olup, annelerin yaş ortalaması 28,7 olarak saptanmıştır. Çalışmaya katılan annelerin \%27,6'sının ilkokul mezunu, \%87,2'sinin ev hanımı olup çalışmadığı, \%63,2'sinin gelir durumunun orta düzeyde olduğu, \%82,4'ünün ise çekirdek ailede yaşadığı belirlenmiştir (Tablo 1).

Tablo 1. Annelerin sosyodemografik özeliklerinin dağılımı

\begin{tabular}{llc}
\hline Özellikler & Sayı & \% \\
\hline Eğitim Durumu (n=250) & 11 & 4,4 \\
Okuryazar değil & 69 & 27,6 \\
İlkokul & 70 & 28,0 \\
Ortaokul & 62 & 24,8 \\
Lise & 38 & 15,2 \\
Üniversite ve üzeri & & \\
\hline Çalışma durumu (n=250) & 32 & 12,8 \\
Çalışıor & 218 & 87,2 \\
Çalısmıyor & & $*$ \\
Çalışanların iş durumu (n=32) & 11 & 34,4 \\
Memur & 8 & 25,0 \\
İşçi & 5 & 15,6 \\
Sağlık çalışanı & 8 & 25,0 \\
Serbest meslek & & \\
\hline Gelir durumu (n=250) & 23 & 9,2 \\
Kötü & 158 & 63,2 \\
Orta & 65 & 26,0 \\
İyi & 4 & 1,6 \\
Çok iyi & & \\
Aile tipi (n=250) & 206 & 82,4 \\
Çekirdek aile & 44 & 17,6 \\
Geniş aile & &
\end{tabular}

*: Yüzde (\%) değeri çalışanların saylsı olan 32'ye göre hesaplanmıştır. 
Annelerin \%36's1 tek, \%40'1 iki, \%24'ü ise üç veya daha fazla çocuk sahibi olduğunu belirtmiştir. Çalışmada, daha önce doğum yapmış olan 160 annenin önceki çocuklarını emzirme durumları incelendiğinde; annelerin \%95,6'sı bebeğini emzirdiğini, \%21,3'ü altı aya kadar, \%51,3 ise bir yıl ve üstünde çocuğunu emzirdiğini, \%4,4'ü bebeğini emzirmediği için ek gıdaya doğumdan sonra hemen, \%70,6'sı 6. aya kadar ek gıdaya başladığını belirtirken, 6. ay ve sonrasında ek gıdaya başladığını ifade eden annelerin oranları ise sadece $\% 25$ 'di.

Annelerin \%74'ü bu bebeğine hamileyken, gebeliği süresince sağlık sorunu yaşamadığını, \%83,2'si isteyerek gebe kaldığını, \%63,6'sı sezeryan ile bebeğini doğurduğunu belirtmiştir. Annelerin \%85,6'sı bu bebeğine hamileyken gebeliği süresince anne sütü ve emzirme ile ilgili bilgi aldığını ifade ederken, bilgi edinme kaynaklarında \%56 ile sağlık personelinin ilk sırada yer aldığı belirlenmiştir. Bilgi aldığını ifade eden 214 annenin \%91,1 gibi büyük çoğunluğu aldığı bilgiyi yeterli bulduğunu belirtmiştir (Tablo 2).

Tablo 2. Annelerin gebelik süreci yaşantılarının dağılımı

\begin{tabular}{lcc}
\hline Değişkenler & Sayı & \% \\
\hline Gebeliği süresince sağlık sorunu yaşama (n=250) & 65 & 26,0 \\
Evet & 185 & 74,0 \\
Hayır & 208 & 83,2 \\
\hline İsteyerek gebe kalma durumu (n=250) & 42 & 16,8 \\
Evet & & \\
Hayır & 91 & 36,4 \\
\hline Doğum şekli (n=250) & 159 & 63,6 \\
Normal & 214 & 85,6 \\
Sezaryan & 36 & 14,4 \\
\hline Anne sütü ve emzirme ile ilgili bilgi alma durumu (n=250) & & $* *$ \\
Evet & 140 & 56,0 \\
Hayır & 76 & 30,4 \\
\hline Bilgi alınma kaynakları (n=290)* & 31 & 12,4 \\
Sağlık personeli & 19 & 8,9 \\
Yakın çevre ve aile büyükleri & 43 & 12,2 \\
Kitap ve dergi & & $* * *$ \\
İnternet, televizyon, radyo & & 91,1 \\
\hline Aldığı bilgiyi yeterli bulma durumu (n=214) & & \\
Yeterli & & \\
Yetersiz & & \\
\hline
\end{tabular}

*: Birden fazla seçenek işaretlenmiştir.

**: Yüzde (\%) değeri genel katıllmcı saylsı olan 250'ye göre hesaplanmiştır.

***: Yüzde (\%) değeri emzirme ile ilgili bilgi alan katılımcı sayısı 214'e göre hesaplanmıştır. 
Çalışmaya katılan annelerin \%61,6'sı 0-2 yaş grubundaki bebeklerini doğumdan sonraki ilk yarım saat içinde, \%9,2'si 24 saat sonrasında emzirmeye başladığını ifade ederken, \%4'ü ise hiç emzirmediğini belirtmiştir. "Anne bir önceki emzirmeden sonra yeni emzirmeye hangi memeden başlamalıdır?" sorusuna annelerin sadece \%26'sı “en son emzirilen memeden" diyerek doğru yanıt vermiştir.

Çalışmada annelere anne sütü ve emzirmeye yönelik bilgiler içeren tek cümleden oluşan 34 ifade verilmiş olup, bunları doğru ya da yanlış olarak değerlendirmeleri istenmiştir. Annelerin \%79,6's1 "Anne sütü sağılıp daha sonra bebeğe verilmek üzere en fazla 12 saat buzdolabında saklanabilir" ifadesini, \%46,8'i "Bebeğin emmediği durumlarda sağılan süt atılır” ifadesini, \%50,8'i "Sağılan süt bebeğe kaşıkla verilmelidir” ifadesini, \%62,8'i “Anne sütünün yeterli olması için tatlı yiyecekler tüketilmelidir" ifadesini, \%41,6's1 "Buzdolabından çıkarılan anne sütü ocakta 1sıtıldıktan sonra bebeğe verilmelidir" ifadesini, \%43,2'si ise "Anne sütü ile beslenen bebeklerin yalancı emzik ve biberon kullanmasında sakınca yoktur" ifadesini yanlış yanıtlamıştır (Tablo 3).

Tablo 3. Annelerin anne sütüne yönelik bilgilerinin sayı ve yüzde değerleri ( $\mathrm{n}=250)$

\begin{tabular}{|c|c|c|c|c|}
\hline \multirow[t]{2}{*}{ İfadeler } & \multicolumn{2}{|c|}{ Evet } & \multicolumn{2}{|c|}{ Hayır } \\
\hline & $\mathbf{n}$ & $\%$ & $\mathbf{n}$ & $\%$ \\
\hline Yenidoğan bebeğe ilk olarak su verilmelidir & 25 & $10,0 *$ & 225 & 90,0 \\
\hline $\begin{array}{l}\text { İlk } 6 \text { ay yalnız anne sütü bebeğin sağlıklı büyümesi ve } \\
\text { gelişmesi için en uygun besindir }\end{array}$ & 238 & 95,2 & 12 & $4,8^{*}$ \\
\hline Anne sütü bebeği bazı hastalıklardan korur & 239 & 95,6 & 11 & $4,4^{*}$ \\
\hline İlk süt (ağız sütü) yenidoğana mutlaka verilmelidir & 227 & 90,8 & 23 & $9,2^{*}$ \\
\hline $\begin{array}{l}\text { Annenin yeterli miktarda siv1 almas1 ve dengeli } \\
\text { beslenmesi sütün miktarını arttırır }\end{array}$ & 234 & 93,6 & 16 & $6,4^{*}$ \\
\hline $\begin{array}{l}\text { Anne sütü sağılıp daha sonra bebeğe verilmek üzere en } \\
\text { fazla } 12 \text { saat buzdolabında saklanabilir }\end{array}$ & 199 & $79,6^{*}$ & 51 & 20,4 \\
\hline Bebeğin emmediği durumlarda sağılan süt atılır & 117 & $46,8^{*}$ & 133 & 53,2 \\
\hline Sağılan süt bebeğe kaşıkla verilmelidir & 123 & 49,2 & 127 & $50,8^{*}$ \\
\hline Ek gidalara doğumdan hemen sonra başlanabilir & 19 & $7,6^{*}$ & 231 & 92,4 \\
\hline $\begin{array}{l}\text { Anne sütünün yeterli olması için tatlı yiyecekler } \\
\text { tüketilmelidir }\end{array}$ & 157 & $62,8^{*}$ & 93 & 37,2 \\
\hline $\begin{array}{l}\text { Buzdolabından çıarılan anne sütü ocakta 1sıtıldıktan } \\
\text { sonra bebeğe verilmelidir }\end{array}$ & 104 & $41,6^{*}$ & 146 & 58,4 \\
\hline Annenin memesi küçükse sütü bebeğine yetmez & 76 & $30,4^{*}$ & 174 & 69,6 \\
\hline $\begin{array}{l}\text { Anne sütü ile beslenen bebeklerin yalanc1 emzik ve } \\
\text { biberon kullanmasında sakınca yoktur }\end{array}$ & 108 & $43,2 *$ & 142 & 56,8 \\
\hline $\begin{array}{l}\text { İlk ayda anne sütü yetmiyorsa öncelikle bebek daha sık } \\
\text { emzirilmelidir }\end{array}$ & 222 & 88,8 & 28 & $11,2 *$ \\
\hline
\end{tabular}


Annelerin \%72'si “Bebek emzirilirken kesinlikle hiçbir ilaç kullanılmamalıdır” ifadesini, önce karbonatlı veya sabunlu suyla temizlenir" ifadesini, \%78,8'i "Emzirme sırasında bebeğin burnunun kapanmaması için meme ucu iki parmak arasında makaslanmalıdır" ifadesini, \%39,2'si "Emzirme süresince göğsü sıkıca saran sütyen kullanılmalıdır”, \%34,8'i "Bebek emzirilirken herhangi bir aile planlaması yöntemi kullanmaya gerek yoktur” ifadesini yanlış yanıtlamıştır (Tablo 4).

Tablo 4. Annelerin emzirmeye yönelik bilgilerinin sayı ve yüzde değerleri $(n=250)$

\begin{tabular}{|c|c|c|c|c|}
\hline \multirow[t]{2}{*}{ İfadeler } & \multicolumn{2}{|c|}{ Evet } & \multicolumn{2}{|c|}{ Hayır } \\
\hline & $\mathbf{n}$ & $\%$ & $\mathbf{n}$ & $\%$ \\
\hline $\begin{array}{lrlll}\begin{array}{l}\text { Annede meme } \\
\text { emzirilmemelidir }\end{array} & \text { ucu } & \text { çatlağı } & \text { varsa } & \text { bebek } \\
\end{array}$ & 91 & $36,4^{*}$ & 159 & 63,6 \\
\hline Emzirmek anneyi meme kanserine karş1 korur & 215 & 86,0 & 35 & $14,0^{*}$ \\
\hline Emzirme süresince sütyen kullanılmamalıdır & 93 & $37,2^{*}$ & 157 & 62,8 \\
\hline $\begin{array}{l}\text { Emzirme anne-bebek bağının kurulmasında yardımcı } \\
\text { olur }\end{array}$ & 221 & 88,4 & 29 & $11,6^{*}$ \\
\hline Emziren annelerin lohusalık kanaması daha az olur & 172 & 68,8 & 78 & $31,2^{*}$ \\
\hline Bebek emzirildikçe annenin süt miktarı artar & 217 & 86,8 & 33 & $13,2^{*}$ \\
\hline $\begin{array}{llll}\text { Bebek emzirilirken } & \text { kesinlikle } & \text { hiçbir } & \text { ilaç } \\
\text { kullanılmamalıdır } & & & \end{array}$ & 180 & $72,0^{*}$ & 70 & 28,0 \\
\hline $\begin{array}{l}\text { Bebeğin ilk emzirilmesine doğumdan sonra ilk yarım } \\
\text { saat içinde başlanılmalıdır }\end{array}$ & 219 & 87,6 & 31 & $12,4^{*}$ \\
\hline $\begin{array}{l}\text { Göğüsler her emzirmeden önce karbonatlı veya sabunlu } \\
\text { suyla temizlenir }\end{array}$ & 178 & $71,2 *$ & 72 & 28,8 \\
\hline $\begin{array}{l}\text { Emzirme sırasında bebeğin burnunun kapanmaması için } \\
\text { meme ucu iki parmak arasında makaslanmalıdır }\end{array}$ & 197 & $78,8^{*}$ & 53 & 21,2 \\
\hline Gece bebeği emzirme, süt üretimini artırır & 178 & 71,2 & 72 & $28,8^{*}$ \\
\hline Her emzirmeden önce eller yıkanmalıdır & 234 & 93,6 & 16 & $6,4^{*}$ \\
\hline $\begin{array}{l}\text { Bebeğin memenin çevresini tamamıla kavrayarak } \\
\text { emmesi meme ucu çatlaklarını önler }\end{array}$ & 190 & 76,0 & 60 & $24,0^{*}$ \\
\hline $\begin{array}{l}\text { Emzirme süresince göğsü sıkıca } \\
\text { kullanılmalıdır }\end{array}$ & 98 & $39,2 *$ & 152 & 60,8 \\
\hline $\begin{array}{l}\text { Bebek emzirilirken herhangi bir aile planlamas1 } \\
\text { yöntemi kullanmaya gerek yoktur }\end{array}$ & 87 & $34,8^{*}$ & 163 & 65,2 \\
\hline Normal bir emzirme süresi $15-20$ dakika olmalıdır & 204 & 81,6 & 46 & $18,4^{*}$ \\
\hline
\end{tabular}


Çalışmaya katılan annelerin bilgi alma durumları ile anne sütüne yönelik ifadelere verdikleri yanıtlar karşılaştırıldı̆̆ında; annelerin bilgi alma durumları ile "yenidoğan bebeğe ilk olarak su verilmelidir" ( $p=0,041)$, "ilk 6 ay yalnız anne sütü bebeğin sağlıklı büyümesi ve gelişmesi için en uygun besindir" ( $p=0,000)$, "anne sütü bebeği bazı hastalıklardan korur" $(p=0,003)$, "annenin yeterli miktarda sıv1 alması ve dengeli beslenmesi sütün miktarını arttırır" ( $\mathrm{p}=0,000)$, "ek gıdalara doğumdan hemen sonra başlanabilir" $(\mathrm{p}=0,000)$ ifadeleri arasında istatistiksel olarak anlamlı fark bulunmuştur (Tablo 5).

Tablo 5. Annelerin bilgi alma durumları ile anne sütüne yönelik ifadelere verdikleri yanıtların ${ }^{2}$ testi İle analiz sonuçları

\begin{tabular}{|c|c|c|c|c|c|c|}
\hline \multirow{4}{*}{ İfadeler } & \multirow{4}{*}{$\begin{array}{l}\text { Bilme } \\
\text { Durumu }\end{array}$} & \multicolumn{5}{|c|}{ Bilgi Alma Durumu } \\
\hline & & \multirow{2}{*}{\multicolumn{2}{|c|}{ Bilgi Alan }} & \multirow{2}{*}{\multicolumn{3}{|c|}{$\begin{array}{l}\text { Bilgi } \\
\text { Almayan }\end{array}$}} \\
\hline & & & & & & \\
\hline & & $\mathbf{n}$ & $\%$ & $\mathbf{n}$ & $\%$ & $x^{2} ; p$ \\
\hline \multirow{2}{*}{$\begin{array}{l}\begin{array}{l}\text { Yenidoğan } \\
\text { verilmelidir }\end{array} \\
\text { bebeğe }\end{array}$} & Biliyor & 196 & 91,6 & 29 & 80,6 & 4,168 \\
\hline & Bilmiyor & 18 & 8,4 & 7 & 19,4 & 0,041 \\
\hline \multirow{2}{*}{$\begin{array}{l}\text { İlk } 6 \text { ay yalnız anne sütü bebeğin sağliklı } \\
\text { büyümesi ve gelişmesi için en uygun } \\
\text { besindir }\end{array}$} & Biliyor & 209 & 97,7 & 29 & 80,6 & 19,738 \\
\hline & Bilmiyor & 5 & 2,3 & 7 & 19,4 & $\mathbf{0 , 0 0 0}$ \\
\hline \multirow[t]{2}{*}{ Anne sütü bebeği bazı hastalıklardan korur } & Biliyor & 208 & 97,2 & 31 & 86,1 & 9,002 \\
\hline & Bilmiyor & 6 & 2,8 & 5 & 13,9 & $\mathbf{0 , 0 0 3}$ \\
\hline \multirow{2}{*}{$\begin{array}{l}\text { İlk süt (ağız sütü) yenidoğana mutlaka } \\
\text { verilmelidir }\end{array}$} & Biliyor & 197 & 92,1 & 30 & 83,3 & 2,807 \\
\hline & Bilmiyor & 17 & 7,9 & 6 & 16,7 & 0,094 \\
\hline \multirow{2}{*}{$\begin{array}{l}\text { Annenin yeterli miktarda sivı alması ve } \\
\text { dengeli beslenmesi sütün miktarını arttırır }\end{array}$} & Biliyor & 206 & 96,3 & 28 & 77,8 & 17,576 \\
\hline & Bilmiyor & 8 & 3,7 & 8 & 22,2 & 0,000 \\
\hline \multirow{2}{*}{$\begin{array}{l}\text { Anne sütü sağılıp daha sonra bebeğe } \\
\text { verilmek üzere en fazla } 12 \text { saat } \\
\text { buzdolabında saklanabilir }\end{array}$} & Biliyor & 46 & 21,5 & 5 & 13,9 & 1,098 \\
\hline & Bilmiyor & 168 & 78,5 & 31 & 86,1 & 0,295 \\
\hline \multirow{2}{*}{$\begin{array}{l}\text { Bebeğin emmediği durumlarda sağılan süt } \\
\text { atılır }\end{array}$} & Biliyor & 109 & 51,0 & 24 & 66,7 & 3,063 \\
\hline & Bilmiyor & 105 & 49,0 & 12 & 33,3 & 0,080 \\
\hline \multirow[t]{2}{*}{ Sağılan süt bebeğe kaşıkla verilmelidir } & Biliyor & 104 & 48,6 & 19 & 52,8 & 0,215 \\
\hline & Bilmiyor & 110 & 51,4 & 17 & 47,2 & 0,643 \\
\hline \multirow{2}{*}{$\begin{array}{l}\text { Ek gidalara doğumdan hemen sonra } \\
\text { başlanabilir }\end{array}$} & Biliyor & 204 & 95,3 & 27 & 75,0 & 18,132 \\
\hline & Bilmiyor & 10 & 4,7 & 9 & 25,0 & 0,000 \\
\hline \multirow{2}{*}{$\begin{array}{l}\text { Anne sütünün yeterli olması için tatlı } \\
\text { yiyecekler tüketilmelidir }\end{array}$} & Biliyor & 81 & 37,9 & 12 & 36,3 & 0,269 \\
\hline & Bilmiyor & 133 & 62,1 & 24 & 66,7 & 0,604 \\
\hline \multirow{2}{*}{$\begin{array}{l}\text { Buzdolabından çıarılan anne sütü ocakta } \\
\text { 1sitıldıktan sonra bebeğe verilmelidir }\end{array}$} & Biliyor & 124 & 57,9 & 22 & 61,1 & 0,127 \\
\hline & Bilmiyor & 90 & 42,1 & 14 & 38,9 & 0,721 \\
\hline \multirow{2}{*}{$\begin{array}{l}\text { Annenin memesi küçükse sütü bebeğine } \\
\text { yetmez }\end{array}$} & Biliyor & 152 & 71,0 & 22 & 61,1 & 1,432 \\
\hline & Bilmiyor & 62 & 29,0 & 14 & 38,9 & 0,231 \\
\hline \multirow{2}{*}{$\begin{array}{l}\text { Anne sütü ile beslenen bebeklerin yalancı } \\
\text { emzik ve biberon kullanmasında sakınca } \\
\text { yoktur }\end{array}$} & Biliyor & 121 & 56,5 & 21 & 58,3 & 0,040 \\
\hline & Bilmiyor & 93 & 43,5 & 15 & 41,7 & 0,841 \\
\hline \multirow{3}{*}{$\begin{array}{l}\text { İlk ayda anne sütü yetmiyorsa öncelikle } \\
\text { bebek daha s1k emzirilmelidir }\end{array}$} & Biliyor & 193 & 90,2 & 29 & 80,6 & 2,874 \\
\hline & Bilmiyor & 21 & 9,8 & 7 & 19,4 & 0,090 \\
\hline & Toplam & 214 & 100,0 & 36 & 100,0 & \\
\hline
\end{tabular}


Çalışmaya katılan annelerin bilgi alma durumları ile emzirmeye yönelik ifadelere verdikleri yanıtlar karşılaştırıldığında; annelerin bilgi alma durumları ile "emzirmek anneyi meme kanserine karşı korur" ( $p=0,002)$, her emzirmeden önce eller yıkanmalıdır" $(p=0,007)$, "bebek emzirilirken herhangi bir aile planlaması yöntemi kullanmaya gerek yoktur" $(p=0,005)$ ifadeleri arasında istatistiksel olarak anlamlı fark bulunmuştur (Tablo 6).

Tablo 6. Annelerin bilgi alma durumları ile emzirmeye yönelik ifadelere verdikleri yanıtların ${ }^{2}$ testi ile analiz sonuçları

\begin{tabular}{|c|c|c|c|c|c|c|}
\hline \multirow{4}{*}{ İfadeler } & \multirow{4}{*}{$\begin{array}{l}\text { Bilme } \\
\text { Durumu }\end{array}$} & \multicolumn{5}{|c|}{ Bilgi Alma Durumu } \\
\hline & & \multirow{2}{*}{\multicolumn{2}{|c|}{ Bilgi Alan }} & \multirow{2}{*}{\multicolumn{3}{|c|}{$\begin{array}{l}\text { Bilgi } \\
\text { Almayan }\end{array}$}} \\
\hline & & & & & & \\
\hline & & $\mathbf{n}$ & $\%$ & $\mathbf{n}$ & $\%$ & $\begin{array}{l}x \\
{ }^{2} ; p\end{array}$ \\
\hline \multirow{2}{*}{$\begin{array}{l}\text { Annede meme ucu çatlağı varsa bebek } \\
\text { emzirilmemelidir }\end{array}$} & Biliyor & 135 & 63,1 & 24 & 66,7 & 0,171 \\
\hline & Bilmiyor & 79 & 36,9 & 12 & 33,3 & 0,679 \\
\hline \multirow{2}{*}{$\begin{array}{l}\text { Emzirmek anneyi meme kanserine karş1 } \\
\text { korur }\end{array}$} & Biliyor & 190 & 88,8 & 25 & 69,4 & 9,574 \\
\hline & Bilmiyor & 24 & 11,2 & 11 & 30,6 & 0,002 \\
\hline \multirow{2}{*}{$\begin{array}{l}\text { Emzirme süresince } \\
\text { kullanılmamalıdır }\end{array}$} & Biliyor & 138 & 64,5 & 19 & 52,8 & 1,808 \\
\hline & Bilmiyor & 76 & 35,5 & 17 & 47,2 & 0,179 \\
\hline \multirow{2}{*}{$\begin{array}{l}\text { Emzirme anne-bebek } \\
\text { kurulmasinda yardımcı olur }\end{array}$} & Biliyor & 190 & 88,8 & 31 & 86,1 & 0,215 \\
\hline & Bilmiyor & 24 & 11,2 & 5 & 13,9 & 0,643 \\
\hline \multirow{2}{*}{$\begin{array}{l}\text { Emziren annelerin lohusalı kanamas1 } \\
\text { daha az olur }\end{array}$} & Biliyor & 148 & 69,2 & 24 & 66,7 & 0,089 \\
\hline & Bilmiyor & 66 & 30,8 & 12 & 33,3 & 0,765 \\
\hline \multirow{2}{*}{$\begin{array}{l}\text { Bebek emzirildikçe annenin süt miktarı } \\
\text { artar }\end{array}$} & Biliyor & 186 & 86,9 & 31 & 86,1 & 0,017 \\
\hline & Bilmiyor & 28 & 13,1 & 5 & 13,9 & 0,895 \\
\hline \multirow{2}{*}{$\begin{array}{l}\text { Bebek emzirilirken kesinlikle hiçbir ilaç } \\
\text { kullanılmamalıdır }\end{array}$} & Biliyor & 59 & 27,6 & 11 & 30,6 & 0,136 \\
\hline & Bilmiyor & 155 & 72,4 & 25 & 69,4 & 0,712 \\
\hline \multirow{2}{*}{$\begin{array}{l}\text { Bebeğin ilk emzirilmesine doğumdan } \\
\text { sonra ilk yarım saat içinde başlanılmalıdır }\end{array}$} & Biliyor & 189 & 88,3 & 30 & 83,3 & 0,705 \\
\hline & Bilmiyor & 25 & 11,7 & 6 & 16,7 & 0,401 \\
\hline \multirow{2}{*}{$\begin{array}{l}\text { Gögüs̈ler her emzirmeden önce karbonatlı } \\
\text { veya sabunlu suyla temizlenir }\end{array}$} & Biliyor & 66 & 30,8 & 6 & 16,7 & 3,019 \\
\hline & Bilmiyor & 148 & 69,2 & 30 & 83,3 & 0,082 \\
\hline \multirow{2}{*}{$\begin{array}{l}\text { Emzirme sırasında bebeğin burnunun } \\
\text { kapanmaması için meme ucu iki parmak } \\
\text { arasında makaslanmalıdır }\end{array}$} & Biliyor & 48 & 22,4 & 5 & 13,9 & 1,346 \\
\hline & Bilmiyor & 166 & 77,6 & 31 & 86,1 & 0,246 \\
\hline \multirow[t]{2}{*}{ Gece bebeği emzirme, süt üretimini arttırır } & Biliyor & 153 & 71,5 & 25 & 69,4 & 0,063 \\
\hline & Bilmiyor & 61 & 28,5 & 11 & 30,6 & 0,801 \\
\hline \multirow[t]{2}{*}{ Her emzirmeden önce eller yıkanmalıdır } & Biliyor & 204 & 95,3 & 30 & 83,3 & 7,400 \\
\hline & Bilmiyor & 10 & 4,7 & 6 & 16,7 & $\mathbf{0 , 0 0 7}$ \\
\hline \multirow{2}{*}{$\begin{array}{l}\text { Bebeğin memenin çevresini tamamıyla } \\
\text { kavrayarak emmesi meme ucu çatlaklarını } \\
\text { önler }\end{array}$} & Biliyor & 164 & 76,6 & 26 & 72,2 & 0,329 \\
\hline & Bilmiyor & 50 & 23,4 & 10 & 27,8 & 0,566 \\
\hline \multirow{2}{*}{$\begin{array}{l}\text { Emzirme süresince göğsü sıkıca saran } \\
\text { sütyen kullanılmalıdır }\end{array}$} & Biliyor & 129 & 60,3 & 23 & 63,9 & 0,168 \\
\hline & Bilmiyor & 85 & 39,7 & 13 & 36,1 & 0,682 \\
\hline \multirow{2}{*}{$\begin{array}{l}\text { Bebek emzirilirken herhangi bir aile } \\
\text { planlamas1 yöntemi kullanmaya gerek } \\
\text { yoktur }\end{array}$} & Biliyor & 147 & 68,7 & 16 & 44,4 & 7,985 \\
\hline & Bilmiyor & 67 & 31,3 & 20 & 55,6 & 0,005 \\
\hline \multirow{3}{*}{$\begin{array}{l}\text { Normal bir emzirme süresi } 15-20 \text { dakika } \\
\text { olmalıdır. }\end{array}$} & Biliyor & 176 & 82,2 & 28 & 77,8 & 0,409 \\
\hline & Bilmiyor & 38 & 17,8 & 8 & 22,2 & 0,522 \\
\hline & Toplam & 214 & 100,0 & 36 & 100,0 & \\
\hline
\end{tabular}




\section{Tartışma}

Bu çalışmada, araştırma kapsamında yer alan annelere ait tanımlayıcı özelliklere, çocuklarını emzirme durumlarına ve sürelerine, anne sütü ve emzirmeye yönelik bilgileri içeren bulgulara yer verilerek, bu bulgular doğrultusunda literatür ile karşılaştırılmıştır. Çalışmaya 250 anne katılmış olup, daha önce doğum yapmış olan 160 annenin önceki çocuklarını emzirme durumları incelendiğinde; annelerin \%95,6 gibi büyük bir çoğunluğu bebeğini emzirdiğini belirtmiştir. NSA 2013 verilerine göre bir süre emzirilen çocukların oranları \%96 olarak saptanmış olup (8), ülkemizde yapılan diğer çalışmalara bakıldığında da emzirme oranlarının (sırasıyla \%96,8; \%94,3) yüksek olduğu görülmüştür $(1,9)$. Son Ulusal Aş1 Araştırmalarına göre, Amerika'nın genel populasyonunda emzirmeye başlama oranı \%75'dir (6). Stuebe ve Bonuck'un (2011) Amerika'da 883 anne ile yaptıkları çalışmada da emzirme oranı \%78,3 olarak bulunmuştur (3). İrlanda, emzirme oranlarının en düşük olduğu ülkelerden biri olup (15), İrlanda'da yapılan bir çalışmaya göre, İrlanda uyruklu olanlarda emzirmeye başlama oranının \%47, diğer uyruklularda ise \%76,6 olduğu (16), Kanada'da yapılan diğer bir çalışmada ise \%62,5 olduğu bildirilmiştir (17). Çalışmadan elde edilen bulgular doğrultusunda ülkemizde emzirmenin diğer ülkelere göre daha yaygın olduğu söylenebilir.

Annelerin önceki çocuklarını emzirme süreleri ve ek gıdaya başlama zamanları incelendiğinde; \%21,3'ü altı aya kadar, \%51,3 ise bir yıl ve üstünde çocuğunu emzirdiğini belirtmiştir. Annelerin \%4,4’ü bebeğini emzirmediği için doğumdan sonra hemen, \%70,6's1 6. aya kadar, \%25'i ise 6. ay ve sonrasında ek gıdaya başladığını ifade etmiştir. İnanç'ın (2013) yaptığı çalışmada; annelerin \%23,5'inin altı aya kadar, \%40,8'inin ise iki yaşına kadar çocuklarını emzirdiği, \%30,9'unun ilk altı ayda anne sütü ile beraber ek gıda verdiği belirlenmiştir (9). Sağlam çocuk polikliniğinde takipli 246 yenidoğan ile yapılan bir çalışmada; altı aylık olduğunda bebeklerin \%52,8'inin sadece anne sütü, \%47,2'sinin ek gıda aldığ bildirilmiştir (18). Diğer bir çalışmada ise bebeklerin sadece anne sütü alma oranları, ikinci ayda \%81.5 iken, dördüncü ayda \%46.2, altıncı ayda ise \%8.7 olarak bulunmuştur (14). TNSA 2013 verilerine göre ise, ülkemizde ortanca sadece anne sütü ile beslenme süresi 1,2 ay, ortanca emzirme süresi ise 16,7 aydır. Altı aydan küçük bebeklerin \%8,1'i emzirilmeyen, \%30,1'i sadece anne sütü, \% 61,7'si ise anne sütü ve ek gıda almaktadır (8). 1991 yılında DSÖ ve UNICEF'in geliştirdiği “Bebek Dostu Hastane" uygulamasından $(10,19)$ sonra bazı ülkelerde emzirmenin geliştirildiği rapor edilse de, bu yerlerin bazılarında da altı ay sadece anne sütü alma oranları düşük kalmaktadır (5). Kanada'da yapılan bir çalışmada, sadece anne sütü alma oranının birinci ayda $\% 39$, üçüncü ayda $\% 4$, altıncı ayda ise sadece anne sütü alan hiçbir bebeğin olmadığı (17), Amerika'da yapılan bir çalışmada ise annelerin sadece $\% 20,2$ 'sinin 7 ay ve üzeri emzirdiği bildirilmiştir (3). Çalışmanın sonuçları literatür ile karşılaştırıldığında; emzirmeye başlama oranlarının yüksek olmasına rağmen, emzirme süresinin ve sadece anne sütü alımının ülkemizde ve yurt dışında yapılan çalışmalara benzer şekilde çalışmada da düşük olduğu, ek gıdaya başlama zamanının ise altı aydan küçük bebeklerde yüksek oranlarda olduğu görülmüştür. Oysaki DSÖ, UNICEF ve Amerikan Pediatri Akademisi bebeklerin doğumdan itibaren ilk altı ay sadece anne sütü ile beslenmesini ve yedinci aydan itibaren ek gıdalar ile birlikte emzirmenin iki 
yaşına kadar devam edilmesini önermektedir. Ayrıca DSÖ, ek gıdalara başlanırken emzirmenin azaltılmaması gerektiğini belirtmektedir $(6,7)$. Çalışmamızda ise önerilen şekilde 6 . ay ve sonrasında ek gıdaya başlayan anne oranının sadece $\% 25$ olduğu, büyük çoğunluğunun 6. aya kadar ek gıdaya başladığı belirlenmiştir.

Annelerin \%85,6'sı anne sütü ve emzirme ile ilgili bilgi aldığını ifade ederken, bilgi edinme kaynaklarında \%56 ile sağlık personeli ve \%30,4 ile yakın çevre ilk iki sırada yer almış olup, \%91,1 gibi büyük çoğunluğu aldığı bilgiyi yeterli bulduğunu belirtmiştir. Anne sütü ile ilgili bilgi alma durumlarının incelendiği bir çalışmada; annelerin \%78,8'inin bilgi aldığı, bu bilgileri \%46,9'unun aile ve çevreden, \%45,3'ünün ise sağlık çalışanlarından edindiği bildirilmiştir (9). Uslu ve ark.'nın (2010) yenidoğan kliniğinde bebekleri yatan 318 anne ile yaptıkları çalışmada, annelerin \%62,9'unun anne sütü hakkında bilgilendirildiği, \%48,1'inin sağlık personeli, \%10,7'sinin ise akraba-arkadaş tarafından bilgilendirildiği belirtilmiştir (20). Diğer bir çalışmada ise, annelerin \%76.1'inin anne sütü ile beslenme hakkında bilgi aldığı, bilgi alınan kaynaklarda ise \%62.2 ile sağlı personelinin ilk sırada olduğu bildirilmiştir (14). Nijerya'da Bebek Dostu bir hastanede 1-24 aylık çocuğu olan 262 anne ile yapılan çalışmada; annelerin \%76,3'ünün emzirme hakkında danışmanlık aldığı (5), Amerika'da Bebek Dostu Hastane uygulamalarının incelendiği diğer bir çalışmada ise; annelerin \%72,8'ine emzirmenin desteklenmesi için eğitim verildiği belirlenmiştir (19). Çalışmadan elde edilen sonuçlar literatür ile karşılaştırıldığında; annelerin anne sütü ve emzirme ile ilgili bilgi edinme oranlarının benzer olduğu görülürken, çalışmada bilgi edinme kaynaklarında sağlık personelinin oranı \%56 iken, Bebek Dostu Hastanelerde yapılan çalışmalarda ise sağlık personelinden eğitim ve danışmanlık alanların oranının daha yüksek olduğu görülmüştür. Ayrıca, çalışmaya katılan annelerin yarısı sağlık personelinden bilgi aldığını ifade ederken, annelerin tamamına yakın bir çoğunluğunun aldığı bilgiyi yeterli bulması istendik olmayan bir sonuç olarak yorumlanabilir.

Çalışmaya katılan annelerin \%61,6'sı 0-2 yaş grubundaki bebeklerini doğumdan sonraki ilk yarım saat içinde, \%9,2'si 24 saat sonrasında emzirmeye başladığını ifade etmiştir. Özer ve ark.'nın (2010) yaptıkları çalışmada; annelerin \%51'i bebeğini doğduktan sonra ilk yarım saat içinde emzirmeye başladığını belirtmiştir (1). Türkiye'de Bebek Dostu Hastane sertifikası olan bir hastanede 577 anne ile yapılan çalışmada; annelerin tümünün 24 saat içinde, \%35,2'sinin bir saat, \%72,8'inin iki saat içinde emzirmeye başladığı bildirilmiştir (10). TNSA 2013 verilerine göre, doğumdan sonraki bir saat içinde emzirilen çocukların oranı \%50'dir (8). Yapılan diğer çalışmalarda ise annelerin doğumdan sonra ilk bir saat içinde emzirmeye başlama oranlarının (sırasıyla \%37,4; \%59,6; \%56,9) çalışmadaki ilk yarım saat içinde emzirmeye başlama oranlarından daha düşük olduğu görülmüştür $(5,11,18)$. Çalışmada, doğumdan sonra emzirmeye başlama zamanlarının diğer çalışmalardaki oranlardan daha yüksek olmasının nedeni, çalışmada normal doğum yapan kadınların $(\% 36,4)$ bulunması ile açıklanabilir. Çünkü yapılan çalışmalarda emzirmeye başlama zamanlarında sezeryan ve normal doğum arasında normal doğum lehine anlamlı farklılıkların olduğu bildirilmiştir (10,11). DSÖ ve UNICEF'in 1991 yılında yayınladığ emzirmeyi başlatmak için annelerin desteklenmesidir. Sezeryan doğumlarda dahil olmak üzere 
doğumdan sonra ilk bir saat içinde emzirmeye başlanması gerektiği bildirilir (6,7). Çalışmada ise emzirmeye bir gün sonra başlayan annelerin bulunması olumsuz bir sonuç olarak yorumlanabilir.

Çalışmada, annelere anne sütü ve emzirmeye yönelik bilgiler içeren tek cümleden oluşan 34 ifade verilmiş olup, bunları doğru ya da yanlış olarak değerlendirmeleri istenmiştir. İfadelerin çoğunu yanlış yanıtlayan annelerin oranı yüksek iken (Tablo 3 ve Tablo 4), anne sütüne yönelik maddelerde anneler tarafından en yüksek oranda bilinenler incelendiğinde; \%95,6 ile "Anne sütü bebeği bazı hastalıklardan korur”, \%95,2 ile "İlk 6 ay yalnız anne sütü bebeğin sağlıklı büyümesi ve gelişmesi için en uygun besindir" ifadeleri yer almıştır. İrlanda'da 322 Çinli anne ile yapılmış çalışmada, annelerin \%82'si "Bebekler için en ideal besin anne sütüdür” derken, \%60'ı anne sütünün bazı hastalıklara karşı koruyucu etkisi olduğunu tanımlamıştır(15). Arslan ve Yeniterzi'nin (2013) preterm bebeklerin anneleri ile yaptıkları çalışmada; “Anne sütünün faydalarını biliyor musunuz?” sorusuna, annelerin \%71'i evet diyerek, \%26'sı büyüme-gelişmeyi sağlar, \%17'si hastalıklardan korur, \%11'i hem büyümeyi hızlandırır hem de hastalıklardan korur diye belirtmiştir (21). Diğer bir çalışmada ise annelerin \% 098,1 ' $\mathrm{i}$ “Tek başına ilk 6 ay bebeğin bütün gereksinimlerini karşılar” ifadesini doğru bilmiştir (1). Annelerin anne sütüne yönelik maddelerde yanlış yanıtladıkları ifadelere bakıldığında ise; \%79,6 ile "Anne sütü sağılıp daha sonra bebeğe verilmek üzere en fazla 12 saat buzdolabında saklanabilir, \%50 ile "Sağılan süt bebeğe kaşıkla verilmelidir", \%43,2 ile "Anne sütü ile beslenen bebeklerin yalancı emzik ve biberon kullanmasında sakınca yoktur”, \%41,6 ile "Buzdolabından çıkarılan anne sütü ocakta 1sıtıldıktan sonra bebeğe verilmelidir" ifadeleri ilk sıralarda yer almıştır. Anne sütü ve emzirme eğitiminin etkinliğini değerlendirmek için yapılan bir çalışmada, eğitim grubundaki annelerin \%36,7'sinin, kontrol grubundakilerin \%58'inin emzik kullandığı, eğitim grubundakilerin \%25,6'sının, kontrol grubundakilerin \%65'inin biberon kullandığ belirtilmiştir (12). TNSA 2013 verilerine göre 6 aydan küçük bebeklerin \%39,7'si biberon kullanmaktadır (8). Yurt dışında yapılan bir çalışmada ise, annelerin $\% 53,1$ 'inin bebeğine emzik verdiği bildirilmiştir (18). Ancak, bebeklerin biberon ve emziğe kolay alışmaları ve sonrasında anneyi emmek istememeleri nedeniyle bunların kullanımı önerilmemektedir (22). DSÖ, biberon ya da emzik kullanımından kaçınılması gerektiğini vurgularken, ek gıdalara geçildiğinde yiyeceklerin biberon ile değil kaşık ya da fincan ile verilmesini önermektedir (7). DSÖ’nün önerilerine rağmen, çalışmada bu ifadeleri yanlış yanıtlayan annelerin oranlarının yüksek olması, biberon ve emzik kullanımının anneler tarafından günümüzde hala tercih ediliyor olması ile açıklanabilir. Ayrıca, çalışmada annelerin anne sütünü saklama ve yeniden kullanma koşulları ile ilgili ifadelere yüksek oranda yanlış yanıt vermeleri bu konuda yetersiz bilgiye sahip olmaları ile açıklanabilir.

Çalışmaya katılan annelerin emzirmeye yönelik maddelerde yanlış yanıtladıkları ifadelere bakıldığında; \%78,8 ile "Emzirme sırasında bebeğin burnunun kapanmaması için meme ucu iki parmak arasında makaslanmalıdır", \%71,2 ile "Gögüsler her emzirmeden önce karbonatlı veya sabunlu suyla temizlenir”, \%39,2 ile “Emzirme süresince göğsü sıkıca saran sütyen kullanılmalıdır” ifadeleri ilk sırada yer almıştır. Emzirmeye yönelik maddelerde anneler tarafından yüksek oranda bilinenler incelendiğinde ise; \%88,4 ile "Emzirme anne-bebek bağının kurulmasında yardımcı olur", \%86,8 ile Bebek emzirildikçe annenin süt miktarı artar”, \%86 ile "Emzirmek anneyi meme kanserine karşı korur" 
ifadeleri dikkat çekicidir. Yapılan bir çalışmada, annelerin \%74,4'ünün "meme kanseri daha az görülür" ifadesini, \%76,3'ünün "bebek ile anne arasında güçlü bir bağ oluşturur” maddelerini doğru bildikleri belirlenmiştir (1). Anne sütünün anneler içinde yararlı olduğu, meme ve over kanseri riskini azalttı̆̆ bildirilmiştir $(4,6,7)$. Çalışmadan elde edilen bulgular doğrultusunda annelerin emzirmenin yararları konusunda bilgilere sahip iken emzirme teknikleri konusunda yeterli bilgiye sahip olmadıkları söylenebilir.

Çalışmaya katılan annelerin bilgi alma durumları ile anne sütü ve emzirmeye yönelik ifadelere verdikleri yanıtlar karşılaştırıldığında, annelerin bilgi alma durumları ile sekiz ifade arasında istatistiksel olarak anlamlı fark bulunmuştur ( $\mathrm{p}<0.05$ ) (Tablo 5 ve Tablo 6). Çalışmada, anne sütü ve emzirme ile ilgili bilgi almayan annelerin bu ifadeleri yanlış yanıtlama oranlarının, bilgi alan annelere göre daha yüksek olduğu görülmüştür. Yapılan bir çalışmada anne sütü ve emzirme ile ilgili annelere verilen eğitimin, sadece anne sütü ile besleme süresini arttırdığı, emzik ve biberon kullanımını anlamlı şekilde azalttığı bildirilmiştir (12). Uslu ve ark.'nın (2010) yaptıkları çalışmada, annelerin bilgilendirilme durumları ile bilgi düzeyleri arasında anlamlı fark olduğu $(\mathrm{p}=0.01)$, özellikle sağlı çalışanları tarafından bilgilendirilmelerinin anne sütü ile beslenme hakkındaki bilgi düzeylerine pozitif yönde katkı sağladığı belirlenmiştir (20). Yapılan diğer çalışmalarda da, annelerin anne sütü ve emzirme ile ilgili bilgilendirilme durumlarının anne sütüyle beslenmeyi (23), ilk altı ay sadece anne sütü alımını $(4,24)$, ilk emzirmeye başlama süresini (18) olumlu yönde etkilediği bildirilmiştir.

Çalışmadan elde edilen bulgular doğrultusunda; çalışmaya katılan annelerin büyük çoğunluğu anne sütü ve emzirme ile ilgili bilgi almış olmalarına rağmen, anne sütü ve emzirmeye yönelik bilgilerinin yeterli olmadığı görülmüştür. Sonuç olarak, sağlık profesyonelleri tarafından anne adaylarına ve annelere anne sütü ve emzirme konusunda eğitim, danışmanlık ve destek programlarının uygulanması önerilir. Ayrıca temel hemşirelik programlarında anne sütü ve emzirme konusu ayrıntılı yer almalı, kanıta dayalı bakım, destek ve danışmanlık uygulamalarını yapabilen hemşirelik öğrencileri ve hemşireler yetiştirilmelidir.

\section{Kaynakça}

1. Özer A, Taş F, Ekerbiçer HÇ. 0-6 aylık bebeği olan annelerin anne sütü ve emzirme konusundaki bilgi ve davranışları. TAF Preventive Medicine Bulletin 2010;9:315-20.

2. Walker A. Breast milk as the gold Standard for protective nutrients. J Pediatr 2010;156:3-7.

3. Stuebe AM, Bonuck K. What predicts intent to breastfeed exclusively? Breastfeeding knowledge, attitudes, and beliefs in a diverse urban population. Breastfeeding Medicine 2011;6:413-20.

4. Imdad A, Yakoob MY, Bhutta ZA. Effect of breastfeeding promotion interventions on breastfeeding rates, with special focus on developing countries. BMC Public Health 2011;11:S24. 
5. Ogunlesi TA. Maternal socio-demographic factors influencing the initiation and exclusivity of breastfeeding in a Nigerian Semi-Urban Setting. Maternal and Child Health Journal 2010;14:459-65.

6. American Academy of Pediatrics (AAP). Breastfeeding and the use of human milk. Pediatrics 2012;129:827-41.

7. World Health Organization (WHO). 10 Facts on Breastfeeding. 2015; http://www.who.int/features/factfiles/breastfeeding/facts/en/index9.html.

8. Türkiye Nüfus ve Sağlık Araştırması (TNSA). Ulusal Toplantı TNSA 2013 Sonuçları. http://www.hips.hacettepe.edu.tr/TNSA2013_sonuclar_sunum_2122014.pdf.

9. İnanç BB. 15-49 yaş arası annelerin anne sütü ile ilgili uygulamaları ve etki eden faktörler. Türk Aile Hekimliği Dergisi 2013;17:51-5.

10. Orun E, Yalcin SS, Madendag Y, Ustunyurt-Eras Z, Kutluk S, Yurdakok K. Factors associated with breastfeeding initiation time in a Baby-Friendly Hospital. Turk J Pediatr 2010;52:10-6.

11. İnce T, Kondolot M, Yalçın SS, Yurdakök K. Annelerin emzirme danışmanlığı alma durumları. Çocuk Sağlığı ve Hastalıkları Dergisi 2010;53:189-97.

12. Onbaşı Ş, Duran R, Çiftdemir NA., Vatansever Ü, Acunaş B, Süt N. Doğum öncesi anne adaylarına verilen emzirme ve anne sütü eğitiminin emzirme davranışları üzerine etkisi. Türk Pediatri Arşivi Dergisi 2011;46:75-80.

13. Spatz DL. The critical role of nurses in lactation support. J Obstet Gynecol Neonatal Nurs 2010;39:499-500.

14. Ünsal H, Atlıhan F, Özkan H, Targan Ş, Hassoy H. Toplumda anne sütü verme eğilimi ve buna etki eden faktörler. Çocuk Sağlı̆̆ı ve Hastalıkları Dergisi 2005;48:226-33.

15. Zhou Q, Younger KM, Kearney JM. An exploration of the knowledge and attitudes towards breastfeeding among a sample of Chinese mothers in Ireland. BMC Public Health, 2010;10:722.

16. Tarrant RC, Younger KM, Sheridan-Pereira M, White MJ, Kearney JM. The prevalence and determinants of breast-feeding initiation and duration in a sample of women in Ireland. Public Health Nutrition 2010;13:760-70.

17. Leger-Leblanc G, Rioux FM. Effect of a prenatal nutritional intervention program on initiation and duration of breastfeeding. Canadian Journal of Dietetic Practice and Research 2008;69:1015.

18. Bolat F, Uslu S, Bolat G, Bülbül A, Arslan S, Çelik M. et al. İlk altı ayda anne sütü ile beslenmeye etki eden faktörler. Çocuk Dergisi 2011;11:5-13.

19. Perrine CG, Scanlon KS, Li R, Odom E, Grummer-Strawn LM. Baby-Friendly Hospital Practices and meeting exclusive breastfeeding intention. Pediatrics 2012;130:54-60.

20. Uslu S, Can E, Özdemir H, Bülbül A. Bir yenidoğan ünitesinde annelerin anne sütü ile beslenme bilgi düzeyleri. Çocuk Dergisi 2010;10:82-5.

21. Arslan FT, Yeniterzi E. Prematüre bebeklerin anne sütü alımı ve ebeveynlerinin görüşleri. Perinatoloji Dergisi 2013;21:77-84. 
22. Vatandaş NŞ. Bebek bakımında aileye öneriler. Sürekli Tıp Eğitimi Dergisi 2004;13:6-8.

23. Renfrew MJ, Craig D, Dyson L, McCormick F, Rice S, King SE. et. al. Breastfeeding promotion for infants in neonatal units: a systematic review and economic analysis. Health Technol Assess 2009;13:1-169.

24. Haroon S, Das JK, Salam RA, Imdad A, Bhutta ZA. Breastfeeding promotion interventions and breastfeeding practices: a systematic review. BMC Public Health 2013;13:S20. 